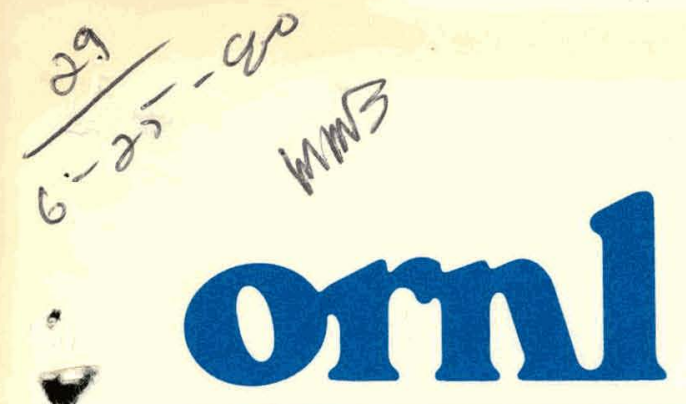

OAK

RIDGE

NATIONAL

LABORATORY

UNION

CARBIDE

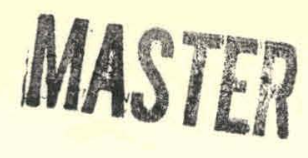

ORNL/TM-7406

\title{
Gamma Exposure Rates Due to Neutron Activation of Soil: Site of Hood Detonation, Operation Plumbbob
}

\author{
J. A. Auxier \\ W. F. Ohnesorge
}

OPERATED BY

UNION CARBIDE CORPORATION FOR THE UNITED STATES DEPARTMENT OF ENERGY 


\section{DISCLAIMER}

This report was prepared as an account of work sponsored by an agency of the United States Government. Neither the United States Government nor any agency Thereof, nor any of their employees, makes any warranty, express or implied, or assumes any legal liability or responsibility for the accuracy, completeness, or usefulness of any information, apparatus, product, or process disclosed, or represents that its use would not infringe privately owned rights. Reference herein to any specific commercial product, process, or service by trade name, trademark, manufacturer, or otherwise does not necessarily constitute or imply its endorsement, recommendation, or favoring by the United States Government or any agency thereof. The views and opinions of authors expressed herein do not necessarily state or reflect those of the United States Government or any agency thereof. 


\section{DISCLAIMER}

Portions of this document may be illegible in electronic image products. Images are produced from the best available original document. 


\section{Printed in the United States of America. Available from National Technical Information Service \\ U.S. Department of Commerce \\ 5285 Port Royal Road, Springfield, Virginia 22161 \\ NTIS price codes-Printed Copy: A02; Microfiche A01}

This report was prepared as an account of work sponsored by an agency of the United States Government. Neither the United States Government nor any agency thereof, nor any of their employees, makes any warranty, express or implied, or assumes any legal liability or responsibility for the accuracy, completeness, or usefulness of any iniormation, apparatus, product, or process disclosed, or represents that its use would not infringe privately owned rights. Reference herein to any specific commercial product, process, or service by trade name, trademark, manufacturer, or otherwise, does not necessarily constitute or imply its endorsement, recommendation, or favoring by the United States Government or any agency thereof. The views and opinions of authors expressed herein do not necessarily state or reflect those of the United States Govermment or any agency thereof. 
Contract No. W-7405-eng-26

\begin{abstract}
Industrial Safety and Applied Health Physics Division
GAMMA EXPOSURE RATES DUE TO NEUTRON ACTIVATION OF SOIL: SITE OF HOOD DETONATION, OPERATION PLUMBBOB
\end{abstract}

J. A. Auxier and W. F. Ohnesorge

Date Published - June 1980

OAK RIDGE NATIONAL LABORATORY

Oak Ridge, Tennessee 37830 operated by UNION CARBIDE CORPORATION

for the DEPARTMENT OF ENERGY 
GAMMA EXPOSURE RATES DUE TO NEUTRON ACTIVATION OF SOIL:

SITE OF HOOD DETONATION, OPERATION PLUMBBOB

J. A. Auxier and W. F. Ohnesorge

\begin{abstract}
This paper is the result of some recent discussions of exposure rates within the first few hours of the Hood detonation of the Plumbbob series due to neutron activation of soil. We estimated the exposure rates from $1 / 2$ to $3 \mathrm{~h}$ after the detonation from ground zero to 1000 yards from ground zero. The area was assumed to be uncontaminated. by fallout.

Soil samples from the area of the Nevada Test Site at which the Hood device was detonated (see Fig. 1) were sent to ORNL by Dr. John Malik of Los Alamos and by Mr. Gordon Jacks of the Nevada Test Site. These samples were irradiated at the DOSAR facility and the resulting activity analyzed. Calculations of exposure rates were then made based on the analyzed activity and the measured thermal neutron fluences at DOSAR and at the Hood Site.
\end{abstract}

Geometry and Source Parameters

The Hood shot was a 74 kiloton device detonated at a height of $457.2 \mathrm{~m}(1500 \mathrm{ft})$ above the surface of the earth. A description of the shot and the resulting neutron fluences are documented in WT-1504. ${ }^{2}$ The exposure rates were calculated for one meter above the surface of the earth; however, the exposure rates changed only slightly from 0.5 meters to more than two meters above the surface. The surface of the earth was treated as an infinite plane source with an activity depth of $30.5 \mathrm{~cm}$ (12 in). The methods used for the volume source calculations were taken from Morgan and Turner. ${ }^{3}$ 


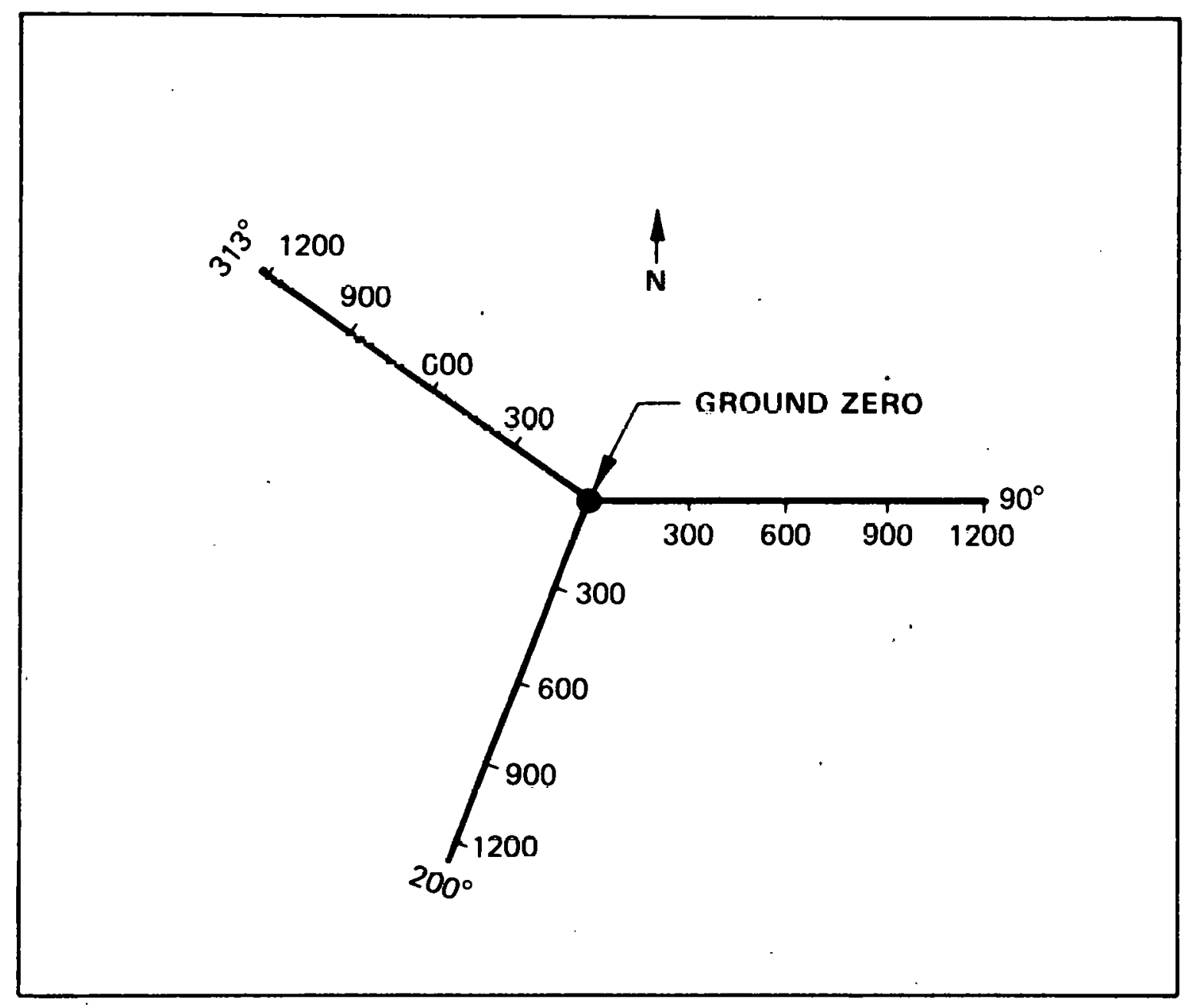

Fig. 1 Soil samples were taken at $300,600,900$, and 1200 yards as shown on each of the radials from ground zero. 
Soil Activity as a Function of Depth

Hood data indicated that the thermal neutron fluence increased from the surface of the earth to a maximum at a depth of $15.2 \mathrm{~cm}$ (6 in). Below this depth the fluence decreased and was about the same as the surface fluence at $30.5 \mathrm{~cm}$ (12 in). The following variation in soil activity was assumed:

$$
\begin{aligned}
& \text { From the surface down to } 15.2 \mathrm{~cm} \\
& \text { Activity }=\text { Activity at Surface } \times\left(1+0.6824 \times \frac{\text { depth }(\mathrm{cm})}{15.2 \mathrm{~cm}}\right) \\
& . \quad \text { From } 15.2 \text { to } 30.5 \mathrm{~cm} \\
& \text { Activity = Activity at Surface } \times\left(1.6824-0.71529 \frac{\operatorname{depth}(\mathrm{cm})-15.2 \mathrm{~cm})}{15.2 \mathrm{~cm}}\right)
\end{aligned}
$$

Dose Rate Calculation:

The following formula was used to calculate the exposure rates:

$E R=\frac{2 \pi N \Sigma n_{i} G_{i}}{\mu_{a l}}\left[\left(E_{2}\left(\mu_{a i r} x d+\mu_{a l} x a\right)-E_{2}\left(\mu_{a i r} x d+\mu_{a l} x a+\mu_{a l} x h\right)\right]\right.$ where,

ER is gamma exposure rate in $R / h$, $\mathrm{N}$ is specific activity in $\mathrm{pCi} / \mathrm{cm}^{3}$, $n_{i}$ is the number of gammas per disintegration of energy $i$, $G_{i}$ is specific gamma constant in $\frac{R-\mathrm{cm}^{2}}{\mathrm{pC} i-h}$ for gamma of energy $i$, $\mu_{a l}$ is the energy absorption cross-section for aluminum in $\mathrm{cm}^{-1}$ (the aluminum cross-section was used because it is similar to that of silicon and other constituent elements of the soil), $\mu_{a i r}$ is the energy absorption cross-section for $\operatorname{air}$ in $\mathrm{cm}^{-1}$, 
$\mathrm{d}$ is distance in air from surface to measurement point in $\mathrm{cm}$,

a is thickness of soil above the source $\mathrm{s} l \mathrm{ab}$ in $\mathrm{cm}$,

$h$ is the thickness of the source $\mathrm{slab}$ in $\mathrm{cm}$.

$E_{2}\left(\mu_{a i r} x d+\mu_{a l} x a\right)$ and $E_{2}\left(\mu_{a i r} x d+\mu_{a l} x a+\mu_{a l} x h\right)$ are the $E$ functions (discussed in Morgan and Turner, chapter nine ${ }^{3}$ ). The E functions were calculated using the following series and recursion formula:

$$
\begin{aligned}
& E_{1}(b)=-0.5772157-\ln (b)+b-\frac{b^{2}}{2 \times 2 !}+\frac{b^{3}}{3 \times 3 !}-\cdots \cdots \cdots \cdots \cdots \\
& E_{2}(b)=e^{-b}-b E_{1} \text { (b) }
\end{aligned}
$$

Since the activity is assumed to vary with depth, the top $30.5 \mathrm{~cm}$ (12 in) of soil was divided into 24 slabs each $1.27 \mathrm{~cm}(0.5 \mathrm{in})$ and the exposure rate was calculated separately for each layer (see Fig. 2). The exposure rates from the layers were summed to give the total exposure rate.

The activity of the soil at the surface per unit thormal flucnce was assumed to be equal to that obtained by the DOSAR irradiation per unit thermal fluence and normalized to zero decay time. The rclative exposure rates from the predominate gammas are shown in Table 1. The thermal fluence due to the DOSAR irradiation was $5.01 \times 10^{11}$ neutrons $/ \mathrm{cm}^{2}$. The exposure rate at the site was calculated by using the following relationship:

Hood exposure rate at zero decay time $=$ DOSAR exposure rate $x$ $\frac{\text { thermal fluence at Hood Site }}{5.01 \times 10^{11}}$ 
ORNL.DWG 80.8332

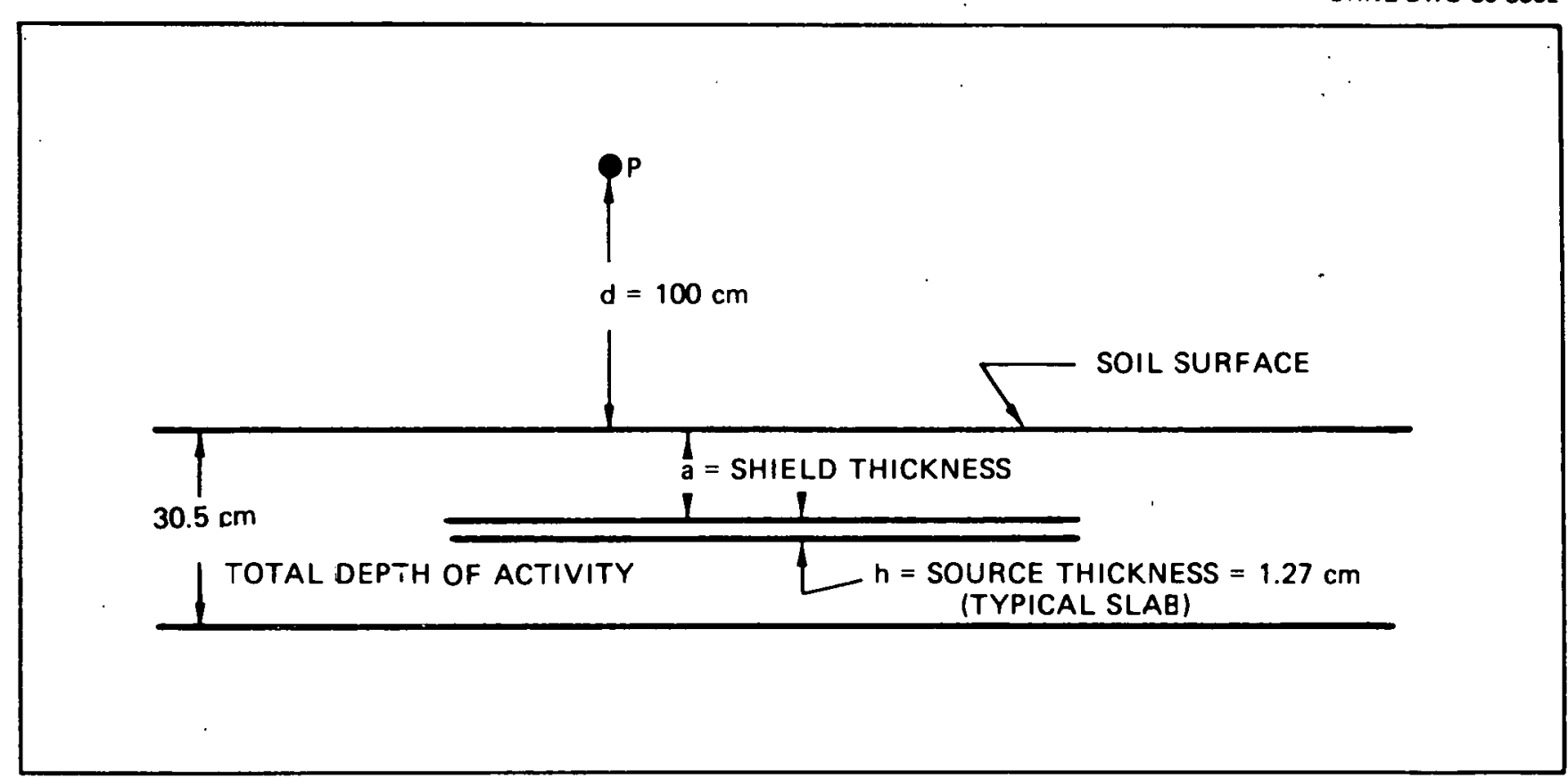

Fig. 2 GEONETRY FOR CALCULATING EXPOSURE - Rate at Point P

(The activated soil is assumed to have the geometry of a truncated cone with planar surface and a thickness of $30.5 \mathrm{~cm}$. ) 
Table 1. Exposure Rates Calculated for Individual Gamma Ray Energies Based on Soil Activity from DOSAR Irradiation

\begin{tabular}{|c|c|c|c|c|c|c|}
\hline \multirow[t]{2}{*}{ Isotope } & \multirow{2}{*}{$\begin{array}{l}\text { Gamma } \\
\text { Energy } \\
\text { (MeV) }\end{array}$} & $\mathrm{T}_{1 / 2}$ & \multicolumn{4}{|c|}{$\begin{array}{l}\text { Dose rate in } \mathrm{mR} / \mathrm{hr} \text { at } 1 \text { meter } \\
\text { above ground as function of } \\
\text { time after } \mathrm{T}_{0} \text { (in hours) }\end{array}$} \\
\hline & &...- & $\ldots \overline{\mathrm{T}}=0.5$ & $\bar{T}=1.0$ & $T=1.5$ & $\mathrm{~T} \equiv 3 . \dot{0}$ \\
\hline \multirow[t]{3}{*}{${ }^{27} \mathrm{Mg}$} & 0.18 & $9.5 \mathrm{~m}$ & $<1$ & $<0.1$ & $<0.1$ & $<0.1$ \\
\hline & 0.84 & & 122.3 & 13.7 & 1.5 & $<0.1$ \\
\hline & 1.01 & & 63.4 & 7.1 & 0.8 & $<0.1$ \\
\hline \multirow[t]{3}{*}{${ }^{56} \mathrm{Mn}$} & 0.847 & $2.58 \mathrm{~h}$ & 13.3 & 11.6 & 10.1 & 6.8 \\
\hline & 1.811 & & 8.1 & 7.1 & 6.2 & 3.6 \\
\hline & 2.110 & & 5.0 & 4.4 & 3.9 & 2.3 \\
\hline \multirow[t]{2}{*}{${ }^{38} \mathrm{Cl}$} & 1.60 & $37.3 \mathrm{~m}$ & 2.3 & 1.3 & 0.7 & 0.1 \\
\hline & 2.17 & & 3.8 & 2.1 & 1.2 & 0.2 \\
\hline \multirow[t]{2}{*}{${ }^{42} \mathrm{~K}$} & 0.31 & $12.5 \mathrm{~h}$ & $<0.1$ & $<0.1$ & $<0.1$ & $<0.1$ \\
\hline & 1.524 & & 0.7 & 0.7 & 0.7 & 0.6 \\
\hline \multirow[t]{2}{*}{${ }^{24} \mathrm{Na}$} & 1.369 & $14.9 \mathrm{~h}$ & 13.4 & 13.1 & 12.8 & 11.9 \\
\hline & 2.754 & & 23.9 & 23.3 & 22.0 & 21.2 \\
\hline \multirow[t]{2}{*}{${ }^{87} \mathrm{Sr}$} & 0,388 & $2.83 \mathrm{~h}$ & 0,1 & 0,1 & 0,1 & 0.1 \\
\hline & & & 256.3 & 84.5 & 60.8 & 46.8 \\
\hline
\end{tabular}


The results of the exposure rate calculations are shown in Table 2 . These values are more than an order of magnitude lower than those given in DASA 1251 but are in accord with values measured by Project 39 personnel during early recovery of dosimeters, i.e. within the first hour after the detonation.

Some Possible Sources of Error:

1. The density of the undisturbed soil is somewhat uncertain. The density of the crushed samples was approximately $1.4 \mathrm{~g} / \mathrm{cm}^{3}$, but a density of $1.6 \mathrm{~g} / \mathrm{cm}^{3}$ was used in the calculations because it was felt that the undisturbed soil was more dense. We believe that the true soil density lies within the range of $1.6 \pm 0.2 \mathrm{~g} / \mathrm{cm}^{3}$. Sensitivity calculations indicate that this would cause less than $\pm 5 \%$ error in the final results.

2. The exact cross-sections were not known and were taken to be the same as those for aluminum. In the range of energies applicable to this problem, the cross-sections for light elements are almost identical. Assuming a maximum of $8 \%$ error in cross-section and using a sensitivity calculation, the maximum error in the final results due to this uncertainty is $\pm 7 \%$.

3. Energy absorption cross-sections were used in the calculations, also we assumed no build-up. A calculation using the simplified assumptions of uniform activity distribution and infinite source thickness indicated a sensitivity of less than $\pm 1 \%$. when build-up factors and total cross-sections were used. 
Table 2. Calculated Gamma Exposure Rates Due to Soil Activation by Hood Device

\begin{tabular}{|c|c|c|c|c|c|c|}
\hline \multirow{2}{*}{$\begin{array}{l}\text { Distance from } \\
\text { Ground Zero } \\
\text { (yards) }\end{array}$} & \multirow{2}{*}{$\begin{array}{l}\text { Slant } \\
\text { Range } \\
\text { (Yurd'j) }\end{array}$} & \multirow{2}{*}{$\begin{array}{l}\phi_{\text {th }} \\
\text { Therma } 1 \\
\text { Fluence } \\
\text { 11/ul! }\end{array}$} & \multicolumn{4}{|c|}{$\begin{array}{c}\text { Dose Rate in } R / h r \text { at } 1 \text { meter above } \\
\text { ground as function of time after } \\
T_{0} \text { (in hours) }\end{array}$} \\
\hline & & & $T=0.5$ & $T \equiv 1 . n$ & $T=1.5$ & $T=3 . n$ \\
\hline 1,000 & 1,118 & $3.25 \times 10^{12}$ & 1.7 & 0.55 & 0.4 & 0.3 \\
\hline 900 & 1,029 & $5.22 \times 10^{12}$ & 2.7 & 0.88 & 0.6 & 0.5 \\
\hline 800 & 943 & $8.36 \times 10^{12}$ & 4.3 & 1.4 & 1.0 & 0.8 \\
\hline 750 & 901 & $1.07 \times 10^{13}$ & 5.5 & 1.8 & 1.3 & 1.0 \\
\hline 700 & 860 & $1.34 \times 10^{13}$ & 6.9 & 2.3 & 1.6 & 1.3 \\
\hline 600 & 781 & $2.13 \times 10^{13}$ & 11 & 3.6 & 2.6 & 2.0 \\
\hline 500 & 707 & $3.35 \times 10^{13}$ & 17 & 5.7 & 4.1 & 3.1 \\
\hline 400 & 640 & $5.16 \times 10^{13}$ & 26 & 8.7 & 6.3 & 4.8 \\
\hline 300 & 583 & $7.57 \times 10^{13}$ & 39 & 13 & 9.2 & 7.1 \\
\hline 200 & 539 & $1.03 \times 10^{14}$ & 53 & 17 & $1 \overline{3}$ & 9.6 \\
\hline 100 & 510 & $1.27 \times 10^{14}$ & 65 & 21 & 15 & 12 \\
\hline 0 & 500 & $1.36 \times 10^{14}$ & 70 & 23 & 17 & 13 \\
\hline
\end{tabular}


4. Uncertainty in determining the soil activity was $\pm 6 \%$.

5. Assume DOSAR fluence accuracy of $\pm 10 \%$.

6. Assume Hood fluence accuracy of $\pm 10 \%$.

7. There is some error associated with assuming a uniform infinite plane source. Sensitivity calculations indicated $15 \%$ greater dose rate from a source with infinite radius than from a source with a radius of 40 meters (44 yards). At a slant range of $914 \mathrm{~m}$ (1000 yards) the soil activity was $30 \%$ higher $40 \mathrm{~m}$ toward ground zero and $15 \%$ lower 40 meters away from ground zero. Since these differences tend to cancel each other, it is felt that the error due to simplified geometry would not exceed $15 \%$.

8. Error caused by assuming no soil activation below $30.5 \mathrm{~cm}$ is less than $8 \%$.

9. Sensitivity calculations were made assuming constant activity of the soil from 0.0 to $30.5 \mathrm{~cm}$ deep and also made using a half-value of $8.64 \mathrm{~cm}$ for attenuation of activity. The results of these calculations were compared with the results obtained which assumed a build-up of activity with depth which reached a maximum activity at $15.2 \mathrm{~cm}$ ( 6 in). These comparisons indicated that the results were not very sensitive to the distribution of activity with depth. The difference in the constant activity model results and the activity build-up model was $29 \%$. The difference between the constant activity model and the one which assumed an attenuation of activity 
with soil depth was 15\%. Any departure from the huili-un model which is based on neutron fluence measurments at the surface, at $15.2 \mathrm{~cm}(6 \mathrm{in})$ and a $30.5 \mathrm{~cm}(1 \mathrm{ft})$ depth at the Hood Site would probably not change the results more than $15 \%$. If the overall uncertainty in the results is equal to the square root of the sum of the squares of the individual uncertainties, the overall uncertainty is $\pm 29 \%$.

Conclusions

In the process of checking the effects of the various uncertainties, it became apparent that final exposure rates were not very sensitive to variation in many of the parameters. It seems that reasonably useful answers are obtained even though a number of simplifying assumptions are made. A programmable calculator was of invaluable assistance in making the calculations and testing the sensitivity to variations in the parameters : 


\section{Acknowledgments}

The authors wish to acknowledge the following for their assistance in making this paper possible. As previously mentioned Gordon Jacks of the Nevada Test Site and John Malik of Los Alamos were responsible for submitting the soil samples. R. L. Clark of ORNL received the samples and was responsible for expediting them through preparation, irradiation, and gamma analysis. M. R. Dunsmore and D. W. Parsons of the ORNL Department of Environmental Management prepared the samples. H. W. Dickson and C. S. Sims of the DOSAR facility were responsible for providing the neutron irradiation and the neutron fluence data. J. S. Eldridge, J. Emery, L. M. Jenkins, H. A. Parker, and T. G. Scott of the ORNL Analytical Chemistry Division provided the gamma ray analysis results. S. A. Hamley of the ORNL Industrial Safety and Applied Health Physics Division provided helpful assistance in obtaining gamma-ray cross sections and in determining the soil density. 


\section{References}

1. Auxier, J. A., "The Health Physics Research Reactor," Health Phys: 11, pg. 89, 1965.

2. Civil Defense Test Group, Operation Plumbbob, Project 39.5, Radiation Dosimetry for Human Exposures, WT-1505, 1958.

3. Morgan, K. Z, and Turner, J. E., Ed(s)., Principles of Radiation Protection, pp. 268-300, Wiley, New York, 1967. 
ORNL/TM-7406

\section{INTERNAL DISTRIBUTION}

1-2. Central Research Library

3. Document Reference Section

4-6. Laboratory Records Department

7. Laboratory Records, ORNL RC

8. ORNL Patent Section
9-18. J. A. Auxier

19. C. D. Berger

20. C. C. Hopkins

21. T. D. Jones

22. W. F. Ohnesorge

\section{EXTERNAL DISTRIBUTION}

23. Bruce W. Church, Nevada Operations Office, DOE, P.O. Box 14100, I.as Vegas, NV 89114.

24. L. J. Deal, Washington Office, DOE, Washington, DC 20545.

25. Gordan Jacks, Nevada Test Site, P.O. Box 435, Mercury, NV 89023.

26. Tom McCraw, Washington Office, DOE, Washington, DC 20545.

27. John Malik, Los Alamos Scientific Laboratory, University of California, P.0. Box 1663, Los Alamos, NM 87545

28. Vice Admiral R. R. Monroe, Defense Nuclear Agency, Hybla Valley Federal Building, Washington, DC 20305.

29. Leon Silverstrom, Nevada Operations Office, DOE, P.O. Box 14100, Las Vegas, NV 89114.

30. Ed Still, Defense Nuclear Agency, Hybla Valley Federal Building, Washington, DC 20305.

31-57. Technical Information Center, Office of Information Services, P.0. Box 62, Oak Ridge, TN 37830 .

58. Bruce Wachholz, Washington Office, DOE, Washington, DC 20545.

59. Asst. Manager for Energy Research \& Development, DOE-ORO 